\begin{tabular}{|c|c|}
\hline Jurnal Kesmas Untika Luwuk: Public Health Journal & 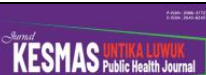 \\
\hline $\begin{array}{l}\text { Volume 11, Nomor 1, Juli } 2020 \\
\text { P-ISSN: 2086-3772, E-ISSN: 2645-8245 }\end{array}$ & \\
\hline Website: https://journal.fkm-untika.ac.id/index.php/phj & \\
\hline This work is licensed under a Creative Commons Attribution 4.0 International License. & $8=$ \\
\hline
\end{tabular}

\title{
Faktor yang Berhubungan dengan Kejadian Pneumonia pada Balita di Kabupaten Bantul Yogyakarta
}

(Factors Related to the Occurrence of Pneumonia in Toddlers in Bantul Regency, Yogyakarta)

\section{Nor Wijayanti*}

Stikes Surya Global Yogyakarta

Koresponden Penulis: wijayantinor@gmail.com

\begin{abstract}
ABSTRAK
Pneumonia merupakan salah satu penyebab dari 4 juta kematian pada balita di negara berkembang, khususnya pada bayi. Pneumonia adalah penyakit infeksi saluran pernafasan yang menyerang bagian bawah paru-paru, yang ditandai dengan batuk dan disertai nafas cepat dan atau nafas sesak serta tarikan kedalam pada dinding dada bagian bawah. Tujuan penelitian ini untuk mengetahui faktor yang berhubungan dengan kejadian pneumonia pada balita di wilayah kerja Puskesmas Bantul. Jenis penelitian ini menggunakan penelitian deskriptif kuantitatif dengan rancangan penelitian studi kasus kontrol. Sampel untuk penelitian ini sebanyak 60 responden yaitu 30 responden kasus dan 30 responden kontrol. Metode analisis data dengan analisis univariat dan bivariat dengan uji chi square dengan tingkat kepercayaan 95\%. HasilPenelitian: Berdasarkan analisis bivariat menunjukkan bahwa variabel bebas yang mempunyai hubungan dengan variabel terikat yaitu Lingkungan $(p=0,031)$, pengetahuan $(p$ $=0,002)$, dan perilaku $(p=0,044)$. Kesimpulan : Ada hubungan yang signifikan antara lingkungan pengetahuan dan perilaku ibu dengan kejadian pneumonia pada balita dan masih kurangnya pengetahuan dan perilaku ibu tentang pneumonia.
\end{abstract}

Kata kunci: Pneumonia, lingkungan, perilaku.

\section{ABSTRACT}

Pneumonia is one of the causes of 4 million deaths in children under five in developing countries, especially in infants. Pneumonia is a respiratory infection that attacks the lower part of the lungs, which is characterized by coughing and is accompanied by rapid breathing and / or shortness of breath and inward traction in the lower chest wall. This study aims to determine the factors associated with the incidence of pneumonia in children under five in the working area of the Bantul Health Center. This type of research uses quantitative descriptive research with a case study control study design. The sample for this study were 60 respondents, 30 case respondents and 30 control respondents. Data analysis method with univariate and bivariate analysis with chi square test with 95\% confidence level. Results: Based on bivariate analysis shows that the independent variables that have a relationship with the dependent variable namely the environment $(p=0.031)$, knowledge $(p=0.002)$, and behavior $(p=0.044)$. Conclusion: There is a significant relationship between the knowledge environment and behavior mothers with the incidence of pneumonia in infants and the lack of knowledge and behavior of mothers about pneumonia.

Keywords: Pneumonia, environment, knowledge, 


\section{PENDAHULUAN}

Pneumonia adalah penyakit infeksi saluran pernafasan yang menyerang bagian bawah paru-paru, yang ditandai dengan batuk dan disertai nafas cepat dan atau nafas sesak serta tarikan kedalam pada dinding dada bagian bawah. Pneumonia umumnya terjadi pada anak kecil, terutama apabila terdapat gizi kurang ditambah dengan keadaan lingkungan yang tidak sehat, seperti terdapat asap rokok di dalam rumah, dan polusi udara. Risiko pneumonia lebih tinggi terjadi pada anak-anak karena mengingatnya kemungkinan infeksi silang, tingginya beban immunologis karena dipakai untuk penyakit parasit dan cacing, serta tidak tersedianya atau berlebihnya pemakaian antibiotik.

Gambar 1. Cakupan Penemuan Pneumonia Pada Balita Di Indonesia Tahun 2008-2017

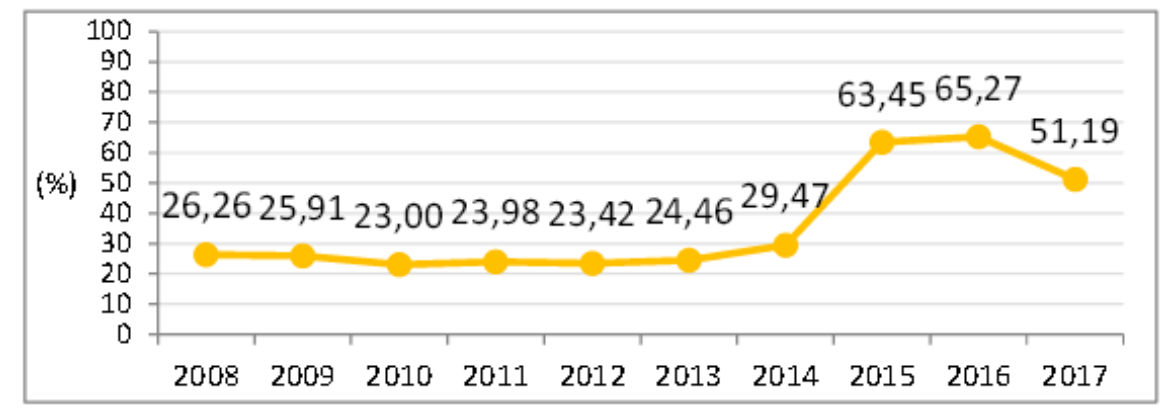

Sumber: Ditjen P2P, Kemenkes RI, 2018

Survei Demografi Kesehatan Indonesia (SDKI) 2017(Kemenkes RI et al., 2018) mengumpulkan informasi tentang morbiditas pada balita melalui serangkaian pertanyaan prevelensi dan praktek pengobatan ISPA (Infeksi Saluran Pernapasan Akut), panas, dan diare. Penyakit-penyakit tersebut merupakan penyakit penyebab kematian anak. Informasi tentang penyakit balita ditanyakan berdasarkan persepsi dan ingatan ibu tanpa informasi catatan medis. Estimasi prevelensi ISPA diperoleh dengan menanyakan kepada ibu, apakah balita mereka pernah sakit dengan batuk, bernafas lebih cepat atau tersengal-sengal dalam dua minggu sebelum survey dan ditanyakan tentang upaya mencari pengobatan. Berdasarkan data yang ada terdapat jumlah anak dengan ISPA sebanyak 693, dengan gejala ISPA (batuk disertai pernapasan pendek dan cepat yang berhubungan dengan dada dan/sulit bernafas yang berhubungan dengan dada) dianggap sebagai proksi untuk pneumonia (Kemenkes RI et al., 2018).

Hasil SDKI tahun 2012 menunjukan bahwa AKBA (Angka Kematian Balita) Daerah Istimewa Yogyakarta (DIY) sebesar 30 per 1000 kelahiran hidup. Sementara itu, profil kesehatan DIY tahun 2012 menyebutkan bahwa AKBA DIY adalah 9,8 per 1000 kelahiran hidup. Hal ini menunjukan bahwa DIY telah memenuhi target Pemerintah Indonesia (32 per 1000 kelahiran hidup). Kasus kematian balita di DIY juga fluktuatif dari tahun 2012-2017, tetapi pada kurun waktu 4 tahun terakhir mengalami penurunan yaitu 454 pada tahun 2014 dan turun menjadi 378 pada tahun 2015, turun lagi menjadi 323 pada tahun 2016 dan naik menajadi 343 pada tahun 2017 (Kemenkes RI et al., 2018).

Jumlah populasi pasien pneumonia pada tahun 2014 - 2015 adalah 496 pasien yang terdiri dari 31 pasien anak dan 281 pasien dewasa di tahun 2014, sedangkan tahun 2015 terdapat 39 pasien anak dan 145 pasien dewasa. Dari total populasi diperoleh subyek penelitian sebanyak 83 pasien yang terdiri dari 25 pasien anak dan 58 pasien 
dewasa. Dari hasil data tersebut dapat diketahui bahwa terjadi penurunan angka kejadian pneumonia pada tahun 2015 (Farida et al., 2017).

Menurut data dari Dinas Kesehatan Kabupaten Bantul (Dinas Kesehatan Bantul, 2017) kasus Pneumonia tertinggi terdapat di daerah Piyungan dengan jumlah 159 orang, namun dalam penelitian ini peneliti melakukan penelitian di daerah Pandak yaitu tertinggi kejadian Pneumonia pada balita yang kedua, karena di Piyungan pada tahun 2016 tercatat 155 orang dan pada tahun 2017 mengalami peningkatan menjadi 159, dan di Pandak pada tahun 2017 terdapat 67 orang dan pada tahun 2018 terdapat kasus 140 orang. Tujuan dari penelitian ini adalah untuk mengetahui faktor yang berhubungan dengan kejadian Pneumonia pada Balita di Kabupaten Bantul DIY.

\section{METODE PENELITIAN}

Penelitian ini adalah penelitian deskriptif kuantitatif yaitu suatu penelitian yang dilakukan untuk mendeskripsikan atau mengambarkan suatu fenomena yang terjadi di dalam masyarakat. Dalam penelitian ini juga menggunakan pendekatan Case Control dimana penelitian (survei) analitik yang menyangkut bagaimana faktor risiko dipelajari dengan menggunakan pendekatan retrospective. Populasi penelitian ini adalah penderita Pneumonia pada balita yang ada di Kabupaten Bantul. Populasi diambil dari 2 puskesmas. Teknik pengambilan sampel dalam penelitian ini menggunakan Total sampling adalah yaitu teknik penentuan sampel bila semua anggota populasi digunakan sebagai sampeli. Sampel dalam penelitian ini sebanyak 30 orang dengan case dan orang dengan control sebanyak 30 orang sehingga total 60 orang. Lokasi penelitian dilakukan di Puskesmas kabupaten Bantul. Penelitian dilaksanakan pada Bulan Oktober 2019.

Teknik Pengambilan Data menggunakan data primer yaitu data yang diperoleh dari puskesmas Kabupaten Bantul dan data sekunder dari rujukan literatur. Teknis analisis data menggunakan univariat dan bivariate mengunakan uji statistik Chi-square.

\section{HASIL}

\section{Analisis univariat}

Pertama, faktor lingkungan. Ibu balita yang mempunyai anak menderita pneumonia yang tinggal di lingkungan baik sebanyak 2 dan ibu yang tidak mempunyai anak menderita sebanyak 9 (18,3\%), ibu balita yang mempunyai anak menderita pneumonia yang tinggal di lingkungan cukup baik sebanyak 13 dan ibu yang tidak mempunyai anak menderita sebanyak 10 (38,3\%), ibu balita yang mempunyai anak menderita pneumonia yang tinggal di lingkungan kurang baik sebanyak 15 dan ibu yang tidak mempunyai anak menderita sebanyak $11(43,3 \%)$.

Kedua, faktor pengetahuan. Ibu balita yang mempunyai anak menderita pneumonia yang mempunyai pengetahuan baik sebanyak 0 dan ibu yang tidak mempunyai anak menderita sebanyak 10 (16,7\%), ibu balita yang mempunyai anak menderita pneumonia yang mempunyai pengetahuan cukup sebanyak 14 dan ibu yang tidak mempunyai anak menderita sebanyak 9 (38,8\%), ibu balita yang mempunyai anak menderita pneumonia yang mempunyai pengetahuan kurang sebanyak 16 dan ibu yang tidak mempunyai anak menderita sebanyak 11 (45,0\%).

Ketiga, faktor perilaku. Ibu balita yang mempunyai anak menderita pneumonia yang mempunyai perilaku baik sebanyak 2 dan ibu yang tidak mempunyai anak menderita sebanyak 9 (18,3\%), ibu balita yang mempunyai anak menderita pneumonia 
yang mempunyai pengetahuan cukup sebanyak 5 dan ibu yang tidak mempunyai anak menderita sebanyak 6 (18,3\%), ibu balita yang mempunyai anak menderita pneumonia yang mempunyai pengetahuan kurang sebanyak 23 dan ibu yang tidak mempunyai anak menderita sebanyak $15(63,3 \%)$.

\section{Analisis Bivariat}

Analisis bivariat yang digunakan dalam penelitian ini adalah uji chi square $\left(x^{2}\right)$. Adanya hubungan antara lingkungan, pengetahuan dan perilaku ibu dengan kejadian pneumonia pada balita ditunjukkan dengan nilai $p<0,05$. Hasil analisa bivariat dalam penelitian adalah sebagai berikut :

Tabel 1. Hubungan Lingkungan ibu dengan kejadian Pneumonia pada Balita di Wilayah Kerja Puskesmas Bantul Pada Tahun 2019

\begin{tabular}{lccccc} 
& \multirow{2}{*}{ Kategori } & \multicolumn{2}{c}{ Frekuensi } & & \multirow{2}{*}{-value } \\
\cline { 2 - 3 } & Kasus & Kontrol & & \\
\hline Baik & 1 & 11 & & 20,0 & \\
Cukup & 13 & 9 & & 40,0 & 0,031 \\
Kurang baik & 16 & 10 & & 40,0 & \\
Total & 30 & 30 & & 100 & \\
\hline
\end{tabular}

Berdasarkan tabel 1 menunjukkan bahwa nilai chi-square signifikan yang dihasilkan sebesar 0,031<0,05 sehingga Ha diterima yang artinya ada faktor hubungan yang signifikan antara lingkungan dengan kejadian pneumonia pada balita di Wilayah Kerja Puskesmas Bantul.

Tabel 2. Hubungan Pengetahuan ibu dengan kejadian Pneumonia pada Balita di Wilayah Kerja Puskesmas Bantul Pada Tahun 2019

\begin{tabular}{lccccc} 
& \multirow{2}{*}{ Kategori } & \multicolumn{2}{c}{ Frekuensi } & & \multirow{2}{*}{-value } \\
\cline { 2 - 3 } & Kasus & Kontrol & & & \\
\hline Baik & 0 & 10 & & 16,7 & \\
Cukup & 14 & 9 & & 38,3 & 0,002 \\
Kurang & 16 & 11 & & 45,0 & \\
Total & 30 & 30 & & 100 & \\
\hline
\end{tabular}

Berdasarkan tabel 2 menunjukkan bahwa nilai chi-square signifikan yang dihasilkan sebesar 0,002 < 0,05 sehingga Ha diterima yang artinya ada hubungan yang signifikan antara pengetahuan ibu dengan kejadian pneumonia pada balita di Wilayah Kerja Puskesmas Bantul.

Tabel 3 di bawah menunjukkan bahwa nilai chi-square signifikan yang dihasilkan sebesar 0,044<0,05 sehingga Ha diterima, yang artinya ada faktor hubungan yang signifikan antara perilaku ibu dengan kejadian pneumonia pada balita di Wilayah Kerja Puskesmas Bantul. 
Faktor yang Berhubungan ... (Wijayanti) $\mid 23$

Tabel 3. Hubungan Perilaku ibu dengan kejadian Pneumonia pada Balita di Wilayah Kerja Puskesmas Bantul Tahun 2019

\begin{tabular}{lccccc} 
& \multirow{2}{*}{ Kategori } & \multicolumn{2}{c}{ Frekuensi } & & \multirow{2}{*}{-value } \\
\cline { 2 - 3 } & Kasus & Kontrol & & \\
\hline Baik & 2 & 9 & 18,3 & \multirow{2}{*}{ Cukup } \\
Kurang & 5 & 6 & 18,3 & 0,044 \\
Total & 23 & 15 & 63,3 & \\
\hline
\end{tabular}

\section{PEMBAHASAN}

\section{Faktor hubungan lingkungan dengan kejadian pneumonia pada balita di wilayah kerja Puskesmas Bantul}

Berdasarkan hasil penelitian faktor hubungan lingkungan ibu dengan kejadian pneumonia pada balita di wilayah kerja Puskesmas Bantul menggunakan uji chi- square pada tabel 10 diketahui sebanyak 30 responden kasus, yang mempunyai lingkungan kurang baik sebanyak 16 orang, Lingkungan yang cukup baik sebanyak 13 orang dan yang tinggal di lingkungan baik sebanyak 1 . Sedangkan responden kontrol sebanyak 30 orang, yang mempunyai lingkungan kurang baik sebanyak 10 orang, lingkungan yang cukup baik sebanyak 9 orang dan tinggal di lingkungan baik sebanyak 11 orang dan didapatkan hasil bahwa terdapat faktor hubungan antara lingkungan ibu dengan kejadian pneumonia pada balita di wilayah kerja Puskesmas Bantul dengan $p$-value 0,031 yang berarti bahwa orang tua yang memiliki lingkungan yang kurang baik memiliki risiko untuk mengalami pneumonia lebih besar dari pada orang tua yang tinggal di lingkungan baik.

Searah dengan penelitian Larasati Fatati dkk. (2019) (Larasati \& Hargono, 2019), Pengetahuan, sikap, dan tindakan merupakan faktor dalam pembentukan perilaku seseorang. Tingkat pengetahuan ibu berbanding lurus dengan perilaku ibu. Kondisi ini disebabkan karena pengetahuan membuat kita bisa memilih mana perilaku yang benar dan harus dilakukan atau mana perilaku yang buruk dan tidak harus dilakukan.

Penelitian ini juga didukung dengan penelitian Rara Alfaqinisa tahun 2015 (Alfaqinisa, 2015) yang meneliti tentang hubungan antara tingkat pengetahuan, sikap, perilaku dan lingkungan orang tua tentang peneumonia dengan tingkat kekambuhan pneumonia pada balita di wilayah kerja Puskesmas Ngersep Kota Semarang yang memperoleh hasil responden kasus yang memiliki lingkungan kurang baik lebih banyak dibandingkan dengan responden kontrol. Dengan $p$-value $=0,011$ sehingga dikatakan bahwa ada hubungan antara lingkungan orang tua tinggal dengan tingkat kekambuhan pneumonia pada balita.

\section{Faktor hubungan pengetahuan dengan kejadian pneumonia pada balita di wilayah kerja Puskesmas Bantul}

Berdasarkan hasil penelitian hubungan pengetahuan ibu dengan kejadian pneumonia pada balita di wilayah kerja Puskesmas Pandak I Bantul menggunakan uji chi- square pada tabel 11 diketahui sebanyak 30 responden kasus, yang mempunyai pengetahuan kurang sebanyak 16 orang, berpengetahuan cukup sebanyak 14 orang dan berpengetahuan baik sebanyak 0 . Sedangkan responden kontrol sebanyak 30 orang, 
yang mempunyai pengetahuan kurang sebanyak 11 orang, pengetahuan cukup sebanyak 9 orang dan berpengetahuan baik sebanyak 10 orang dan didapatkan hasil bahwa terdapat hubungan antara pengetahuan ibu dengan kejadian pneumonia pada balita di wilayah kerja Puskesmas Bantul dengan p-value 0,002 yang berarti bahwa orang tua yang memiliki tingkat pengetahuan kurang baik memiliki risiko untuk mengalami pneumonia lebih besar dari pada orang tua yang memiliki tingkat pengetahuan baik.

Berdasarkan hasil penelitian dilapangan bahwa terdapat perbedaan tingkat pengetahuan antara responden kasus dan responden kontrol. Responden kasus memiliki tingkat pengetahuan kurang lebih banyak yaitu 16 orang sedangkan responden kontrol memiliki tingkat pengetahuan kurang lebih sedikit yaitu 11 orang. Dari hasil wawancara beberapa responden bahwa masih kurangnya pengetahuan ibu-ibu tentang penyakit pneumonia dan masih kurang tahu tentang penyebab pneumonia. Dan dari hasil observasi peneliti ketika penelitian di rumah warga masih terdapatnya kandang ternak yang berdekatan dengan rumah sehingga udara di rumah menjadi kurang baik.

\section{Faktor Hubungan Perilaku Ibu dengan Kejadian Pneumonia pada Balita di Wilayah Kerja Puskesmas Bantul}

Berdasarkan hasil penelitian hubungan perilaku ibu dengan kejadian pneumonia pada balita di wilayah kerja Puskesmas Bantul menggunakan uji chi- square didapatkan hasil bahwa terdapat faktor yang berhubungan antara perilaku ibu dengan kejadian pneumonia pada balita di wilayah kerja Puskesmas Bantul dengan p-value 0,044. Berdasarkan hasil penelitian dilapangan bahwa terdapat perbedaan tingkat perilaku antara responden kasus dan responden kontrol. Responden kasus memiliki tingkat perilaku kurang lebih banyak yaitu 23 orang sedangkan responden kontrol memiliki tingkat perilaku kurang lebih sedikit yaitu 15 orang. Dari hasil penelitian dan wawancara terhadap responden terdapat ibu-ibu yang masih kurang memperhatikan kebersihan rumah. Masih terdapat ibu yang tidak membersihkan rumahnya setiap hari yang mengakibatkan lantai rumah berdebu dan dapat membahayakan balita apabila menghirup debu tersebut.

Faktor predisposisi (predisposing factors) yang terwujud dalam pengetahuan, sikap, kepercayaan, keyakinan dan nilai-nilai. Faktor pendukung (enabling factors) meliputi terwujud dalam lingkungan fisik, tersedia atau tidak tersedianya fasilitasfasilitas atau sarana-sarana kesehatan, misalnya puskesmas, obat-obatan, alat kontrasepsi, dan jamban. Faktor pendorong (reinforcing factors) meliputi sikap dan perilaku petugas kesehatan atau petugas lain yang merupakan kelompok referensi dari perilaku masyarakat. Disimpulkan bahwa perilaku seseorang atau masyarakat tentang kesehatan ditentukan oleh pengetahuan, sikap, kepercayaan, dan tradisi dari orang aau masyarakat yang bersangkutan (Notoatmodjo, 2015).

\section{KESIMPULAN DAN SARAN}

Berdasarkan pada hasil penelitian dan pembahasan yang telah diuraikan, maka dapat diambil kesimpulan sebagai berikut, 1) Ada faktor yang berhubungan antara lingkungan ibu balita tinggal dengan kejadian pneumonia di wilaya kerja Puskesmas Bantul. 2) Ada faktor yang berhubungan antara pengetahuan ibu dengan kejadian pneumonia di wilayah kerja Puskesmas Bantul sebagian besar mempunyai pengetahuan kurang baik. 3) Ada faktor hubungan antara perilaku ibu dengan kejadian pneumonia di wilayah kerja Puskesmas Bantul sebagian besar mempunyai perilaku kurang baik. 4) 
Faktor yang Berhubungan ... (Wijayanti) $\mid 25$

Ada faktor hubungan yang signifikan antara lingkungan ibu balita tinggal, pengetahuan dan perilaku dengan kejadian pneumonia pada balita di wilayah kerja Puskesmas Bantul.

Saran bagi petugas di Puskesmas Bantul, untuk bisa meningkatkan media komunikasi, informasi, dan edukasi mengenai pneumonia kepada masyarakat dengan media yang tersedia seperti poster, leaflet, atau film sehingga dapat meningkatkan pengetahuan dan perilaku ibu tentang pneumonia untuk dapat mengurangi risiko terjadinya pneumonia pada balita. Bagi warga yang memiliki balita, diharapkan agar dapat meningkatkan kebersihan lingkungan tempat tinggal, pengetahuan dan perilaku yang sehat seperti tidak merokok di dalam rumah, membuka jendela setiap hari dan lebih sering membersihkan rumah setiap hari. Bagi sesama peneliti, penelitian ini bisa menjadi rujukan untuk penelitian lebih lanjut dengan jenis desain penelitian yang berbeda tentang pneumonia pada balita.

\section{UCAPAN TERIMA KASIH}

Ucapan terima kasih peneliti ucapkan kepada: 1) STIKes Surya Global Yogyakarta selaku Institusi yang memberikan dana penelitian dan dukungan, 2) LPPM STIKes Surya Global Yogyakarta selaku wadah pengembangan dan peningkatan kegiatan Tridharma 3) Puskesmas dan Petugasnya, lokasi pengambilan data penelitian. 4) pihak - pihak yang telah membantu terlaksananya penelitian ini.

\section{DAFTAR PUSTAKA}

Alfaqinisa, R. (2015). Hubungan Antara Tingkat Pengetahuan, Sikap, Dan Perilaku Orang Tua Tentang Pneumonia Dengan Tingkat Kekambuhan Pneumonia Pada Balita Di Wilayah Kerja Puskesmas Ngesrep Kota Semarang Tahun 2015. Jurusan Ilmu Kesehatan Masyarakat Fakultas Ilmu Keolahragaan Universitas Negeri Semarang.

Dinas Kesehatan Bantul. (2017). Profil Kesehatan Bantul 2017. In Profil Kesehatan Kab.Bantul.

Farida, Y., Trisna, A., \& Nur, D. (2017). Studi Penggunaan Antibiotik Pada Pasien Pneumonia di Rumah Sakit Rujukan Daerah Surakarta. Journal of Pharmaceutical Science and Clinical Research. https://doi.org/10.20961/jpscr.v2i01.5240

Kemenkes RI, Badan Kependudukan dan Keluarga Berencana Nasional, \& RISKESDAS. (2018). Survei Demografi dan Kesehatan 2017. In Riset Kesehatan Dasar 2018. https://doi.org/1 Desember 2013

Larasati, F., \& Hargono, A. (2019). Perbedaan Risiko Pneumonia Berdasarkan Pola Asuh dan Paparan Asap Rokok. Jurnal PROMKES. https://doi.org/10.20473/jpk.v7.i2.2019.163-172

Notoatmodjo, S. 2014. I. P. K. J. R. C. (2015). Ilmu Perilaku Kesehatan. Jakarta: Rineka Cipta. In Biomass Chem Eng. 